\title{
SINERGI PEMBERDAYAAN MASYARAKAT DALAM PENGEMBANGAN WISATA DESA, KERAJINAN DAN PERTANIAN BERKELANJUTAN DI KECAMATAN KUBUTAMBAHAN KABUPATEN BULELENG
}

\author{
Oleh:
}

\author{
Ida Bagus Jelantik Swasta, dkk \\ Universitas Pendidikan Ganesha (Undiksha)
}

\section{A. Abstrak dan Kata Kunci}

Program Ipteks bagi Wilayah di Kecamatan Kubutambahan, Kabupaten Buleleng, Propinsi Bali adalah program yang bertujuan untuk memberdayakan potensi masyarakat secara partisipatif melalui pemberian bantuan ilmu pengetahuan dan teknologi dalam mengembangkan potensi-potensi unggul yang ada di Kecamatan Kubutambahan untuk meningkatkan kesejahteraan masyarakat secara berkelanjutan. Bidang-bidang yang menjadi fokus perhatian dalam program ini adalah bidang pertanian dan peternakan, kerajinan dan wirausaha, pariwisata, lingkungan hidup, dan kesehatan. Sementara itu, beberapa desa yang menjadi sasaran dalam program ini adalah Desa Bukti, Desa Bulian, Desa Depeha, dan Desa Tunjung. Program ini dilaksanakan melalui metode PALS (Participatory Action and Learning System) yang diterjemahkan menjadi berbagai bentuk kegiatan seperti pendidikan dan pelatihan (diklat), penyuluhan, pembinaan dan pendampingan, pelayanan, pemberian bantuan modal, dan bakti sosial. Adapun hasil dari kegiatan ini adalah ; 1) meningkatnya pengetahuan dan keterampilan masyarakat petani dalam budidaya tanaman kelapa unggul, tanaman obat, tanaman bumbu / rempah dapur ; 2) meningkatnya pengetahuan dan keterampilan masyarakat peternak sapi dan babi dalam melakukan pemeliharaan dan membiakkan ternak mereka ; 3) meningkatnya pengetahuan dan keterampilan masyarakat pesisir di Desa Bukti dalam bidang budidaya perikanan laut ;4) meningkatnya pengetahuan dan keterampilan para pengrajin anyaman bambu dan kerajinan kertas dalam membuat disain dari kerajinan mereka ; 5) meningkatnya pengetahuan dan keterampilan masyarakat wirausaha desa dalam meningkatkan kualitas minyak VCO hasil produksi mereka ; 6) meningkatnya status kesehatan masyarakat sebagai hasil kegiatan safari kesehatan dan penyuluhan di bidang kesehatan ; 6) tertatanya dengan baik lingkungan dan hijaunya kembali sejumlah lahan kritis yang ada di empat desa sasaran ; 7) tertatanya dengan baik taman-taman sekolah khususnya di sekolah-sekolah dasar yang ada di empat desa sasaran ; 8) terbentuknya kelompok pemandu wisata spiritual yang siap mendukung berkembangnya wisata spiritual di Kecamatan Kubutambahan ; dan 9) adanya pengetahuan dan keterampilan di bidang kepemanduan wisata spiritual pada sejumlah pemuda desa sebagai hasil diklat dibidang kepemanduan wisata spiritual.

Kata-kata Kunci : Pemberdayaan, Masyarakat, Ilmu Pengetahuan, Teknologi 


\section{B. Pendahuluan}

Sebagai salah satu kecamatan di Kabupaten Buleleng, maka kecamatan Kubutambahan merupakan kecamatan yang memiliki sumbangan yang cukup besar bagi pertumbuhan ekonomi Buleleng secara menyeluruh. Dikatakan demikian karena disamping wilayahnya cukup luas, Kecamatan Kubutambahan tergolong sebagai kecamatan yang memiliki potensi pertanian, peternakan, perikanan, kerajinan, industri rumah tangga dan pariwisata yang cukup besar bilamana dikelola secara sungguhsungguh. Diantara desa-desa yang ada di kecamatan ini, maka empat desa yang manjadi sasaran program Iptek bagi Wilayah (IbW) seperti desa Bukti, Bulian, Depeha dan Tunjung merupakan desa-desa yang juga memiliki potensi-potensi itu. Potensi pertanian yang cukup menonjol di desa-desa ini adalah pertanian lahan kering, terutama perkebunan mangga dan rambutan (di Desa Depeha dan Bulian), perkebunan kelapa (di Desa Bukti), perkebunan cengkeh, cokelat dan kopi (di Desa Tunjung). Potensi peternakan yang cukup menonjol di desa-desa ini adalah peternakan sapi, babi dan ayam. Terkait dengan potensi perikanan, maka dari empat desa yang menjadi sasaran program IbW, hanya Desa Bukti yang memiliki potensi perikanan, khususnya perikanan laut. Potensi kerajinan yang ada adalah kerajinan anyaman bambu, ingka dan kerajinan cenderamata. Industri rumah tangga yang ada adalah usaha kuliner (jajan, kerupuk, dodol, kacang), usaha pembuatan batako, usaha pembuatan minyak VCO. Sementara itu, potensi pariwisata yang ada adalah wisata pantai, wisata sepiritual dan wisata agro berbasis mangga. Wisata pantai yang cukup potensial untuk dikembangkan lebih lanjut adalah obyek wisata Air Sanih. Sementara itu obyek wisata spiritual yang cukup potensial untuk dikembangkan adalah sejumlah pura yang ada di empat desa sasaran seperti Pura Pucak Bukit Dulang (Bukti), Pura Majagana dan Pura Banua (Bulian), Pura Yeh Kedis (Depeha), dan Pura Yeh Tabah (Tunjung).

Kendatipun ke empat desa (Bukti, Bulian, Depeha dan Tunjung) memiliki potensi pertanian, peternakan, perikanan, kerajinan dan pariwisata yang cukup besar, namun karena kurangnya kemampuan masyarakat di dalam mengelolanya, maka sektor pertanian, peternakan, perikanan, kerajinan dan pariwisata itu belum mampu meningkatkan kesejahteraan masyarakat secara signifikan. Disamping karena kurangnya kemampuan masyarakat dalam mengelola sumberdaya alam, maka masih rendahnya tingkat kesejahteraan masyarakat juga disebabkan karena belum semua potensi tenaga kerja yang ada bergerak melakukan proses produksi. Rendahnya 
tingkat kesejahteraan masyarakat dapat dilihat dari masih tingginya tingkat kemiskinan, rendahnya status gizi dan kesehatan, rendahnya tingkat pendidikan, dan masih tingginya angka pengangguran di masyarakat. Terkait dengan kemiskinan, data tentang jumlah KK miskin di keempat desa tersebut pada tahun 2009 secara berturut-turut mencapai $589 \mathrm{KK}$ (Bukti), 435 KK (Bulian), $352 \mathrm{KK}$ (Depeha), dan 578 KK (Tunjung). Sementara itu, terkait dengan angka pengangguran, data tentang jumlah pengangguran di keempat desa tersebut pada tahun 2009 secara berturut-turut adalah 356 orang (Bukti), 320 orang (Bulian), 692 orang (Depeha), dan 458 orang (Tunjung).

Terkait dengan kekurang mampuan masyarakat dalam mengelola sumberdaya alam yang ada, maka hal ini disebabkan oleh kurangnya pengetahuan dan keterampilan pada masyarakat dalam hal meningkatkan produksi dan memasarkan hasil produksi dari usaha pertanian, peternakan, kerajinan dan industri yang ditekuni oleh masyarakat. Disamping itu akses masyarakat pada permodalan dan teknologi juga masih sangat kurang sehingga usaha-usaha yang ditekuni masih terkesan tradisional, konvensional dan tidak berorientasi bisnis. Sementara itu, belum maksimalnya jumlah tenaga kerja yang mengelola sumberdaya alam adalah juga disebabkan oleh belum dimilikinya pengetahuan dan keterampilan oleh sebagian masyarakat yang sesungguhnya sudah memasuki usia kerja.

Akhirnya, dengan masih rendahnya tingkat kesejahteraan masyarakat di empat desa tersebut sebagai akibat belum maksimalnya pengelolaan sumberdaya alam yang ada dan sebagai akibat belum maksimalnya penggerakan tenaga kerja yang ada, maka munculah suatu gagasan untuk memberdayakan masyarakat melalui maksimalisasi pemanfaatan sumberdaya alam dan potensi sumberdaya manusia yang ada di empat desa tersebut. Pemberdayaan masyarakat melalui maksimalisasi pemanfaatan sumberdaya alam dan potensi sumberdaya manusia ini diharapkan dapat meningkatkan kesejahteraan masyarakat di empat desa sasaran. Munculnya gagasan ini adalah didasari oleh adanya kesadaran bahwa perguruan tinggi (Undiksha dan Unipas) sudah sepantasnya ikut menyumbangkan karya nyata untuk meningkatkan kesejahteraan masyarakat di sekitar kampus termasuk masyarakat di empat desa sasaran.

Terlaksananya program Ipteks bagi Wilayah (IbW) di Kecamatan Kubutambahan tahun 2011 diinspirasi oleh beberapa kondisi dan kebutuhan riil yang ada di empat desa yang menjadi sasaran program. Beberapa kondisi riil yang 
dimaksud adalah ; 1) belum berdayanya masyarakat petani dan peternak di empat desa sasaran walaupun potensi pertanian (khususnya pertanian lahan kering) dan potensi peternakan di empat desa sasaran cukup tinggi ;2) belum berdayanya masyarakat nelayan yang ada di pesisir Desa Bukti walaupun potensi perikanan laut yang ada di sepanjang pesisir Desa Bukti cukup tinggi ; 3) belum berkembangnya berbagai kerajinan dan industri rumah tangga yang ada di empat desa sasaran walaupun potensi kerajinan (khususnya kerajinan anyaman bambu, ingka, cenderamata) dan industri rumah tangga (khususnya $\mathrm{VCO}, \mathrm{KCO}$, kuliner) di empat desa sasaran cukup tinggi ; 4) belum berkembangnya wawasan kewirausahaan pada masyarakat di empat desa sasaran walaupun potensi usaha dan tenaga kerja di desa cukup tinggi ; 5) belum berkembangnya sektor pariwisata di empat desa sasaran walaupun potensi wisatanya (khususnya wisata pantai, wisata agro dan wisata spiritual) cukup baik ; 6) belum optimalnya status kesehatan masyarakat di empat desa sasaran sebagai akibat dari sulitnya memperoleh air bersih, kemiskinan dan kurangnya pengetahuan masyarakat dalam hal cara-cara memelihara kesehatan diri dan keluarga ; dan 7) belum optimalnya kualitas lingkungan hidup sebagai akibat tipikal iklim yang kering dan kurangnya kesadaran masyarakat dalam hal membina dan memelihara lingkungan hidup yang sehat dan indah.

Terkait dengan beberapa kondisi riil di atas, maka beberapa hal yang dibutuhkan oleh ke empat desa sasaran adalah ; 1) upaya pemberdayaan masyarakat petani (khususnya petani mangga, kelapa, cengkeh, cokelat dan kopi) dan peternak (khususnya peternak sapi, babi dan ayam) di empat sasaran melalui pemberian pengetahuan, keterampilan, dan permodalan di bidang pertanian dan peternakan ; 2) upaya pemberdayaan masyarakat nelayan di pesisir Desa Bukti melalui pemberian keterampilan dibidang teknik budidaya perikanan laut ; 3) upaya pengembangan kerajinan dan industri rumah tangga melalui pemberian pendidikan dan pelatihan di bidang pengembangan jenis dan disain produk, manajemen usaha, serta melalui pemberian bantuan modal kerja, pembentukan koperasi, dan jasa pendampingan ; 4) upaya pengembangan sektor wisata spiritual melalui pembentukan kelompok pemandu dan melalui penataan lingkungan sejumlah pura yang menjadi objek wisata spiritual ; 5) upaya meningkatkan status kesehatan masyarakat melalui pemberian penyuluhan kesehatan dan layanan pengobatan secara gratis ; dan 6) upaya perbaikan lingkungan hidup melalui kegiatan reboisasi di sejumlah lahan kritis dan penanaman tanaman hias di pinggir-pinggir jalan di seputar pusat desa, penataan 
taman-taman sekolah, dan pengelolaan sampah organik melalui diklat pembuatan pupuk kompos secara mekanik.

\section{Materi dan Metode Pelaksanaan}

Materi (bahan dan alat) yang digunakan dalam kegiatan ini sangat banyak, terutama materi (bahan dan alat) yang disumbangkan kepada mayarakat sebagai modal perangsang dan materi (bahandan alat) yang gunakan dalam kegiatan pendidikan dan pelatihan. Bahan dan alat yang telah disumbangkan sebagai modal perangsang meliputi; 1) sebuah mesin pemotong kertas untuk industri kerajinan cenderamata di Desa Bulian; 2) lima ratus butir bibit kelapa unggul untuk masyarakat petani kelapa di Desa Bukti; 3) sembilan ekor ternak sapi dan 10 ekor ternak babi untuk kelompok peternak di empat desa sasaran; 4) beberapa perangkat alat berkebun dan bahan kimia dan biologis untuk pembuatan kompos untuk petani cokelat, kopi dan cengkeh di Desa Tunjung; 5) sebuah alat pembuat pupuk kompos untuk kelompok tani di Desa Bulian; 6) ribuan bibit tanaman keras (tanaman hutan) untuk masyarakat pemilik lahan kering di empat desa sasaran; 7) ribuan tanaman hias untuk pengembangan taman sekolah di delapan sekolah dasar (SD) di empat desa sasaran dan untuk perindangan jalan desa di Desa Bulian; 8) sejumlah obat-obatan untuk peningkatan kesehatan masyarakat di empat desa sasaran; 9) sejumlah bahanbahan yang digunakan dalam diklat pembuatan dan pengembangan disain anyaman bambu di Desa Depeha.

Metode pelaksanaan kegiatan yang diterapkan dalam upaya untuk mencapai tujuan program adalah metode pemberdayaan masyarakat yang dikenal dengan nama metode PALS (Participatory Action and Learning System) yang dikembangkan oleh Linda Mayouk pada tahun 2000 (Chambers, 2007). Metode PALS ini merupakan salah satu metode yang masuk dalam lingkup metode PLA (Participatory Learning Action) yang merupakan hasil perubahan dari metode RRA (Rapid Rural Appraisal). Beberapa prinsip dasar dari metode PALS ini adalah; 1) menempatkan masyarakat di desa sasaran sebagai objek dan sekaligus sebagai subjek kegiatan; 2) pelaksanaan program menggunakan berbagai pendekatan; 3) pelaksanaan program berfokus pada kebutuhan atau kepentingan masyarakat; 4) program-program memiliki sifat pemecahan masalah, pemberdayaan masyarakat dan pengembangan wilayah; 5) 
pelaksanaan program bersifat sistemik; dan 6) pelaksanaan program bersifat mencerdaskan dan meransang aktivitas masyarakat.

Dalam program sibermas ini, masyarakat dilibatkan mulai dari proses perencanaan, proses pelaksanaan hingga proses monitoring dan evaluasi kegiatan. Dalam tahap perencanaan, tim pelaksana program sibermas mengajak perwakilan masyarakat di empat desa sasaran untuk ikut merencanakan kegiatan yang akan dilaksanakan di masing-masing desa. Pada tahap ini tim pelaksana sibermas menggali informasi dari masyarakat tentang hal-hal yang diperlukan dan diinginkan oleh masyarakat dan tentang potensi-potensi yang ada di desa yang dapat dipakai sebagai modal untuk memenuhi keperluan dan keinginan masyarakat. Informasi tentang halhal yang diperlukan dan potensi-potensi yang dimiliki oleh masyarakat ini kemudian dipakai dasar oleh tim pelaksana program sibermas untuk merencanakan bentukbentuk kegiatan. Dalam tahap pelaksanaan, masyarakat di empat desa secara bersama-sama diajak untuk melaksanakan kegiatan dengan difasilitasi oleh tim pelasana program sibermas. Dalam kegiatan yang berbentuk pendidikan dan pelatihan (diklat), masyarakat diposisikan sebagai peserta diklat, sedangkan tutor dan narasumbernya diperankan oleh tim pelaksana sibermas dan sejumlah narasumber dari luar tim pelaksana program. Dalam kegiatan yang berbentuk pembinaan dan pendampingan terhadap usaha / industri, masyarakat pemilik dan pengelola usaha / industri diposisikan sebagai pihak yang dibina dan didampingi. Sementara itu pembina atau pendampingnya diperankan oleh tim pelkasana program sibermas dan beberapa pakar wirausaha dan ekonomi. Dalam kegiatan yang berbentuk bhakti sosial lingkungan hidup, masyarakat diposisikan sebagai partisipan kegiatan yang diprakarsai oleh tim pelaksana program sibermas. Dalam kegiatan yang berbentuk bhakti sosial (safari) kesehatan, masyarakat di posisikan sebagai sasaran kegiatan yang dilayani oleh tim dokter yang sengaja di bawa ke desa oleh tim pelaksana program sibermas. Dalam kegiatan yang berbentuk pembangunan sarana dan prasarana fisik, masyarakat diposisikan sebagai pihak yang menjadi sasaran kegiatan yang di sediakan sarana-prasarana fisik yang menjadi kebutuhannya. Dalam kegiatan yang berbentuk penyuluhan, masyarakat di posisikan sebagai peserta (sasaran) penyuluhan. Sementara penyuluhnya sendiri diperankan oleh sejumlah pakar yang diambil dari Undiksha dan Unipas. 


\section{Hasil dan Pembahasan}

Hasil-hasil yang dicapai selama dan setelah selesainya kegiatan sibermas (IbW) ini adalah; a) dibidang revitalisasi sektor pertanian telah terjadi perbaikan cara berkebun cengkeh dan cokelat melalui teknik pemilihan dan penanaman bibit yang benar, pemberian pupuk kompos, penerapan teknik pemberantasan yang ramah lingkungan yang semuanya kelak diharapkan dapat meningkatkan produksi dan kualitas biji cokelat dan cengkeh; b) dibidang revitalisasi peternakan telah terjadi perbaikan dalam cara pemilihan bibit ternak, perbaikan cara pemeliharaan, dan perbaikan teknis pengembangbiakan yang semuanya kelak diharapkan dapat meningkatkan produksi dan kualitas ternak, khususnya ternak sapi dan babi; c) dibidang penerapan Iptek, keterampilan hidup dan wirausaha telah terjadi peningkatan kualitas dan kuantitas produksi cenderamata, peningkatan kualitas disain anyaman bambu, peningkatan produksi ingka produksi VCO dari usaha-usaha rumah tangga sebagai akibat pembinaan, pemberian bantuan Iptek dan pemberian bantuan modal yang diberikan oleh tim pelaksana program sibermas ( $\mathrm{IbW})$; d) dibidang penerapan Iptek juga telah dihasilkan mesin pembuat pupuk kompos (pencincang sampah organik); e) dibidang pembinaan lingkungan hidup telah terbentuk lingkungan desa yang bersih, sejuk dan indah, serta taman sekolah yang asri sebagai akibat dari gerakan penghijauan dan penanaman tanaman hias yang dilakukan secara bersamasama oleh masyarakat desa dan sejumlah dosen Undiksha dan Unipas di bawah koordinasi tim pelaksana program sibermas; f) pembinaan lingkungan hidup juga telah membuat sejumlah lahan kritis di empat desa sasaran menjadi hijau kembali sebagai akibat penanaman tanaman hutan yang dilakukan secara bersama-sama oleh masyarakat dan sejumlah dosen Undiksha dan Unipas di bawah koordinasi tim pelaksana program sibermas; g) pembinaan lingkungan hidup juga telah membuat taman-taman sekolah di sejumlah sekolah dasar menjadi lebih asri sebagai hasil diklat dibidang penataan taman sekolah yang diikuti oleh sejumlah guru dari sekolahsekolah yang menjadi sasaran; h) dibidang pembinaaan sektor pariwisata telah berhasil dibentuk kelompok pemandu wisata spiritual dan telah berhasil pula direalisasi warung stop over untuk promosi dan pemasaran produk-produk kerajinan yang menopang kepariwisataan di Kecamatan Kubutambahan; i) dalam bidang pembinaan keluarga harapan telah berhasil dilakukan pemeriksaan kesehatan dan pengobatan gratis kepada sekitar 450 orang warga masyarakat di empat desa sasaran; 
dan j) dibidang kewirausahaan telah berhasil dibentuk koperasi pengerajin yang siap menopang jalannya usaha para pengerajin di empat desa sasaran.

Kalau dikaji secara lebih mendalam tentang keberhasilan program sibermas (IbW) dalam perbaikan cara berkebun cengkeh dan cokelat di Desa Tunjung, serta tanaman kelapa unggul di Desa Bukti maka hal ini tidak terlepas dari tepatnya pendekatan yang ditempuh dalam memperkenalkan Iptek dibidang budidaya tanaman kelapa, cengkeh dan cokelat kepada masyarakat petani Dalam hal ini, pendekatan yang menjadi penyebab keberhasilan ini adalah pendekatan pendidikan dan pelatihan. Melalui pendidikan, masyarakat petani diberikan pengetahuan teori tentang budidaya tanaman kelapa, cengkeh dan cokelat, sedangkan melalui pelatihan para petani dan peternak diberikan kesempatan untuk berlatih keterampilan di bidang budidaya tanaman kelapa, cengkeh dan cokelat. Selain karena pendekatan yang tepat, maka keberhasilan ini juga disebabkan karena tepatnya konten materi yang diberikan dalam diklat. Dalam hal ini, konten tentang cara memilih dan menanam bibit yang baik, cara membuat dan menggunakan pupuk kompos yang baik, cara membasmi hama dan penyakit yang ramah lingkungan merupakan hal-hal yang sangat diperlukan dalam budidaya pertanian yang ramah lingkungan yang sudah terbukti memberikan keberhasilan dalam dunia pertanian.

Terkait dengan keberhasilan program sibermas (IbW) dalam meningkatkan jumlah dan kualitas produk kerajian cenderamata, kerajinan anyaman bambu, ingka, industri VCO, maka keberhasilan ini juga tidak terlepas dari ketepatan dalam memilih pendekatan. Dalam hal ini, pendekatan yang dipandang tepat adalah pendekatan diklat di tahapan awal dan pendekatan pembinaan dan pendampingan serta pemberian bantuan modal di tahap berikutnya. Pendekatan diklat di tahap awal digunakan untuk memberikan masukan pengetahuan dan keterampilan kepada para pengrajin dan pekerja tentang bagaimana membuat disain, meningkatkan mutu, dan meningkatkan kecepatan produksi dari usaha kerajinan dan usaha industri yang ditekuni. Sementara itu, pendekatan pembinaan, pendampingan dan pemberian bantuan modal dimaksudkan untuk menjamin keberlanjutan usaha dan menjaga keajegan mutu produk.

Keberhasilan program sibermas ( $\mathrm{IbW}$ ) dalam memperbaiki kondisi lingkunngan di empat desa sasaran adalah disebabkan oleh adanya gerakan penghijauan dan gotong royong kebersihan yang dirancang berbasis masyarakat. Dalam hal ini tim pelaksana program sibermas $(\mathrm{IbW})$ meransang keterlibatan masyarakat secara 
langsung dalam kegiatan bhakti sosial lingkungan. Dengan cara demikian, maka rasa memiliki lingkungan di kalangan masyarakat menjadi tinggi, sehingga masyarakat secara sadar ikut memelihara lingkungannya.

Terkait dengan keberhasilan program sibermas (IbW) dalam merintis wisata sepiritual di empat desa sasaran adalah tidak terlepas dari pendekatan yang ditempuh. Dalam hal ini, tim pelaksana sibermas ( $\mathrm{IbW}$ ) mengajak para pakar pariwisata, para tokoh adat dan agama dan para praktisi wisata untuk ikut merumuskan konsep wisata sepiritual dan penterapannya, yang kemudian dilanjutkan dengan upaya mengajak para pemuda yang belum memiliki pekerjaan tetap untuk belajar menjadi pemandu wisata spiritual dan membentuk kelompok pemandu wisata spiritual.

Keberhasilan program sibermas dalam meningkatkan status kesehatan masyarakat di empat desa sasaran adalah disebabkan oleh pelayanan kesehatan yang berkualitas yang diberikan oleh dokter-dokter yang berpengalaman yang sengaja dibawa ke desa dalam kegiatan safari kesehatan gratis yang diprakarsai oleh tim pelaksana program sibermas. Dalam hal ini masyarakat diberikan pelayanan berupa pemeriksaan kesehatan dan pengobatan secara gratis yang bertempat di balai desa masing-masing.

\section{E. Kesimpulan dan Implikasi}

Sebagai kesimpulan dapat disampaikan bahwa pelaksanaan program sibermas di Kecamatan Kubutambahan pada tahun 2011 telah berhasil dalam hal; a) membenahi teknik budidaya tanaman cengkeh dan cokelat di Desa Tunjung, dan budidaya kelapa unggul di Desa Bukti yang kelak diharapkan dapat meningkatkan jumlah produksi dan kualitas cengkeh, cokelat dan kelapa di desa itu ; b) meningkatkan pengetahuan dan keterampilan masyarakat pesisir di Bukti dalam bidang budidaya perikanan laut ; c) meningkatkan jumlah dan kualitas produk kerajinan cenderamata, kerajinan anyaman bambu, anyaman ingka, industri pembuatan VCO, khususnya di Desa Bulian, Desa Depeha dan Desa Tunjung ; d) membuat prototipe mesin pembuat pupuk kompos ; e) meningkatkan pengetahuan dan keterampilan para peternak dalam hal teknis beternak sapi dan babi serta meningkatkan gairah usaha ternak mereka melalui pemberian bantuan bibit ternak sapi dan babi ; f) menggerakkan sektor kepariwisataan sepiritual sebagai dampak dari pembentukan kelompok pemandu wisata sepiritual ; g) membenahi kualitas lingkungan hidup di empat desa sasaran melalui gerakan penghijauan, diklat penataan 
taman sekolah, dan pemberian bantuan dana penataan taman sekolah ; dan h) meningkatkan status kesehatan masyarakat di empat desa sasaran melalui pengobatan gratis, penyuluhan kesehatan dan diklat pembuatan makanan sehat dan bergizi bagi balita dan anak-anak ; i) terbentuknya koperasi pengerajin yang siap menopang usaha kerajinan di empat desa sasaran

Beberapa dampak dan manfaat yang dihasilkan oleh pelaksanaan program Ipteks bagi Wilayah (IbW) ini adalah ; 1) adanya perbaikan dalam teknik budidaya tanaman cengkeh, cokelat di Desa Tunjung dan kelapa unggul di Desa Bukti ; 2) adanya pembenahan dalam teknik beternak sapi dan babi ; 3) tumbuhnya peluang usaha baru di bidang budidaya perikanan laut di Desa Bukti ; 4) meningkatnya jumlah dan kualitas produk kerajinan cenderamata, kerajinan anyaman bambu, kerajinan ingka, produk industri rumah tangga (VCO) ; 5) terciptanya prototipe mesin pembuat pupuk kompos ; 6) terbentuknya kelompok pemandu wisata spiritual

; 7) terpromosikannnya produk-produk kerajinan masyarakat melalui peanfaatan warung stop over yang ada di ODTW Air Sanih ; 8) meningkatnya kualitas lingkungan yang ditunjukkan oleh tertanaminya sejumlah lahan kritis dengan tanaman hutan dan tertanaminya pinggiran jalan diseputar desa dengan tanaman hias tanaman bunga seperti tanaman kenanga, cempaka, palm, glodogan, dan bougenvile, serta semakin asrinya taman-taman sekolah ; 9) meningkatnya status kesehatan masyarakat, dan ; 10) terbentuknya koperasi pengerajin.

\section{F. Ucapan Terima Kasih}

Atas suksesnya pelaksanaan program IbW di Kecamatan Kubutambahan ini, maka melalui tulisan ini saya sampaikan ucapan terima kasih yang sebesar-besarnya kepada ; 1) Pemerintah Daerah Kabupaten Buleleng atas dukungan dana dan kepercayaannya sehingga program dapat berjalan dengan baik ; 2) para kepada desa di empat desa sasaran yang telah mendukung pelaksanaan program ini ; 3) seluruh lapisan masyarakat di empat desa sasaran yang dengan tulus telah berpartisipasi dalam seluruh kegiatan ; 4) seluruh rekan-rekan Undiksha dan Unipas yang tergabung dalam tim pelaksana program IbW yang dengan penuh tanggung jawab dalam merencanakan dan melaksanakan kegiatan ; dan 5) LPM Undiksha dan LPM Unipas yang telah mendukung terlaksananya kegiatan IbW ini. 


\section{G. Daftar Pustaka}

Anonim, 2010, Buleleng dalam Angka, 2009, BPS Buleleng, Singaraja.

Anonim, 2010, Kubutambahan dalam Angka Tahun 2009, BPS Buleleng, Singaraja.

Anonim, 2008, RPKAD Kabuoaten Buleleng, Pemda Buleleng, Singaraja.

Chambers, R., 2007, From PRA to PLA and Pluralism, Practice and Teory, IDS, Working

Paper 286, Brigton : Institute of Development Studies. 